\title{
Implementation Of Higher Order Thinking Skills (Hots) In 2013 Curriculum Assessment To Improve Pedagogic Competence And Teacher Professionalism
}

\author{
Qurrota Ayu Neina, M.Pd. \\ \{neina@mail.unnes.ac.id\} \\ Department of Indonesian Language and Literature Faculty of Languages and Arts, Universitas Negeri \\ Semarang
}

\begin{abstract}
For a teacher, pedagogical competence is an ability that must always be improved.The aim of this article is to describe the steps to improve pedagogical competence and professionalism of teachers through the implementation of Higher Order Thinking Skills (HOTS) in the 2013 Curriculum assessment. In order to achieve such goal, evaluation activities in learning must be carried out comprehensively, including 1) the evaluation of learning outcomes in the early stage of learning, 2) the evaluation of learning outcomes at the learning process stage, 3 ) the evaluation of learning outcomes at the final stages of learning, and 4) the evaluation of learning outcomes at the follow-up stage of learning. The formulation of the comprehensive evaluation was implemented by making HOTS-based instruments. It intends to maximize students' learning outcomes, improve critical thinking skills, motivate students to be competitive, and have adequate literacy insights.
\end{abstract}

Keywords: Evaluation, HOTS, pedagogic, assessment, 2013 Curriculum

\section{Introduction}

Teachers as professionals are expected to improve their dignity and role as learning agents to improve the quality of national education. In realizing it, teachers should have four basic competencies in accordance with Article 8 of Undang-Undang Republik Indonesia number 14 of 2005 covering pedagogical competencies, personality competencies, social competencies, and professional competencies [1]. Pedagogic competence is the ability of teachers in learning management, one of which is the ability to evaluate learning [2]. Learning evaluation can be implied as a process to determine the quality of learning as a whole, starting from the planning stage of the learning process, the implementation of the learning process, to the assessment of learning outcomes [3]. The evaluation activity is carried out to control, guarantee, and determine the quality of learning outcomes [4].

Based on the results of field observations, it is discovered that many teachers cannot make evaluation tools, both from the realm of knowledge, skills, and attitudes even though the evaluation activities possess an objective in finding out the level of understanding of students towards the subject matter. Moreover, the evaluation activity is also expected to be able to build students' courage and invite them to recall the material that has been taught, as well as 
to find out the level of the behavioral changes in students that eventually can be used as a feedback tool to improve teaching and learning processes and remedial programs for students [5]. Based on those objectives, it can be concluded that the evaluation process plays an important role in advancing the learning process in schools. One of the forms of evaluation in the 2013 curriculum is Higher Order Thinking Skills (HOTS). Higher Order Thinking Skills is one of the measurement methods used to measure the skill of higher-order thinking, namely the ability to think that includes the ability to remember (recall), retell (restate), and refer without doing processing (recite) [6]. The method is realized through the problems or instruments which require the students to achive the higher order thinking skills, namely problem solving, decision making, critical thinking and creativity [7].

Presentment of HOTS-based questions in the assessment process can train students to hone their abilities and skills in accordance with the demands of 21 st-century competence, namely: a) possessing good character (devout and piety, curiosity, persistent, socially and culturally sensitive, adaptable, and high competitive); b) possessing a number of competencies (critical and creative thinking, problem solving, collaboration, and communication); and c) mastering literacy includes thinking skills using knowledge sources in print, visual, digital and auditory forms. Through assessment according to HOTS-based questions, critical thinking skills, creativity, and self-confidence, will be built through training activities in solving various real problems in daily life.

To realize this, a learning measurement tool that stimulates students to think actively, collaboratively, and participatively is needed [8]. In other words, learning instruments are expected to be at a higher level in various aspects, both in the cognitive, affective, and psychomotor aspects. It provides an opportunity for teachers to implement evaluation activities at HOTS level. Teachers are expected to be able to arrange the instruments proportionally and systematically to measure Competency Achievement Indicators (IKK) effectively and have depth so that students are encouraged to answer the analysis process [9].In other words, the teacher must arrange questions that the answer not only at the level of knowing (C-1), understanding (C-2), and implementing (C-3), but also at the level of analyzing (C-4), evaluating (C-5), and creating (C-6).

However, in practice of the implementation of the HOTS level evaluation is not an easy thing to do by the teacher. Besides that the teacher must really master the material and learning strategies, they are also faced with challenges related to the environment and intake of students they teach. Therefore, a refresher is needed as well as providing in-depth understanding to teachers through the implementation of HOTS (Higher Order Thinking Skill) in the 2013 curriculum. It is expected to improve pedagogical competence, especially in terms of learning evaluation, so that teacher professionalism will increase.

\section{Research Methods}

The research method used in this article is a qualitative research. This research model aims to understand social phenomena from the perspective of participants [10]. This study examines the phenomenon of the assessment process in the 2013 curriculum conducted by teachers. It is hoped that from this study an assessment system can be found which can improve the pedagogical ability of teachers. It was strived in order to increase professionalism in learning. The steps of collecting and analyzing data are carried out through five stages, as follows: 
1) Planning

Planning activities include the formulation and limitation of problem activities as well as formulating research questions directed at data collection activities. The planning activities in this study focus on solving the problem of how to improve pedagogical abilities and applying assessment which is in accordance with the 2013 curriculum in order to improve teacher professionalism.

2) Begin the data collection

Before data collection is started, a good relationship is created from the beginning by fostering trust and close relationship with individuals and groups who are the source of the data. Data collection through interviews is then complemented with observational data and document data (triangulation).

3) Collecting the basic data

Data collection is intensified by in-depth interviews, observation, and collection of more intensive supporting documents.

4) Collecting the final data

Data collection ends after getting all the information needed and no new data is found.

5) Complementing

This step is done by complementing the data analysis and devising how to present it. Data analysis begins by compiling the facts of the findings found in the field and then developed into principles.

\section{Result And Discussion}

\subsection{Improvement of Teacher Pedagogic Competence and Professionalism in the 2013 Curriculum}

The quality of Indonesian education can be improved in the right way. Fernandez stated that one way to improve the education quality is to strengthen teacher competence so that all its potential can be maximized [11]. Various competencies that must be mastered by teachers are included in pedagogical competencies. Teacher pedagogical competency variables are measured through seven indicators, one of which is the ability of teachers to evaluate learning outcomes, which mean that teachers are able to design and carry out process evaluations and learning outcomes on an ongoing basis with various methods, analyzing the results of process evaluations and learning outcomes to determine the level of completeness of learning, and utilizing the results of learning assessments to improve the quality of learning programs in general [12].

Learning evaluation generally becomes part of the learning supervision activities [13]. Learning supervision activities include monitoring, supervision and evaluation activities. The learning evaluation is done to determine the learning quality as a whole. Evaluation activities include the planning stages of the learning process, the implementation of the learning process, and the assessment of learning outcomes. Each of these stages has an element of learning outcomes assessment in order to provide quality assurance of learning outcomes.

To increase teacher professionalism, the evaluation activities in learning must be carried out comprehensively. The context of comprehensive evaluation of learning outcomes is interpreted as broad and complete evaluation activities related to the scope or content. Therefore, a comprehensive evaluation of learning outcomes is interpreted as an evaluation of learning outcomes that are thorough, possessing an extent or a content scope and a complete 
period of time. The evaluation that was carried out comprehensively consisted of four stages, namely: 1) the evaluation of learning outcomes in the early stage of learning, 2) the evaluation of learning outcomes at the learning process stage, 3 ) the evaluation of learning outcomes at the final stages of learning, and 4) the evaluation of learning outcomes at the follow-up stage of learning. Learning outcomes evaluation in the early stages of learning begins with conducting an analysis of the students' initial abilities (intake), the competencies complexity and learning material in the curriculum, and the carrying capacity (supporting learning infrastructure and human resources). The results of the analysis are used to determine the minimum passing criteria (KKM) which will be used as a basis for guaranteeing the quality of learning outcomes. The objective of learning outcomes evaluation in the early learning stage is planning the measurement of learning outcomes consisting of 1) the quality of learning inputs, 2) the accuracy of determining the minimum passing criteria (KKM) for each basic competency, 3) the accuracy of the formulation of learning outcomes, and 4) the accuracy of the measurement instrument of learning outcomes.

Then, the next stage of evaluation is the implementation of learning outcomes assessment in the learning process. The goal of learning outcomes evaluation at the learning process stage is the accuracy of implementation in the measurement of learning outcomes in the aspects of knowledge, skills, and attitudes. It is carried out through the process of measuring using the right instruments. The instrument can be performed in the form of tests and non-tests.

The next evaluation activity is carried out on the processing and utilization of learning outcomes at the end of learning. The objective of learning outcomes evaluation in the final stages of learning is the accuracy of the processing and formulation of achievement of learning outcomes in aspects of knowledge, skills, and attitudes. The basis for determining success in this process is the achievement of learning objectives that have been determined at the beginning of learning.

The last evaluation activity was done on the follow-up of learning outcomes assessment at the follow-up learning stage. The objective of learning outcomes evaluation in the follow-up learning stages is the accuracy of the utilization of learning outcomes assessment and the follow-up learning evaluation. Standard of success for students can be seen from the KKM that has been determined at the beginning. These obtained results will determine the follow-up to be done by the teacher. If students get a score exceeding the KKM will be used as a basis by the teacher to carry out the enrichment process. On the contrary, if students get a score below the KKM, the follow-up that is done is the remedial process.

In formulating learning activities, teachers had better conduct a comprehensive evaluation process. This comprehensive evaluation process can guarantee the success of the learning process and improve pedagogical abilities in order to realize teacher professionalism. In addition, Wagiran also stated that the evaluation activities carried out comprehensively also had several functions, including: 1) providing feedback for students to know their strengths and weaknesses in the process of achieving competence. 2) Monitoring the progress as well as diagnosing learning difficulties experienced by students. 3) Feedback for teachers in improving methods, approaches, learning activities, teaching materials, media and learning resources used. 4) Feedback for teachers to design more meaningful learning activities. 5) Providing information to parents and education unit committees about the effectiveness of the learning management. 6) Providing feedback for policy makers (Principals and related agencies) in carrying out evaluations of the administration of education in the regions. 


\subsection{The Implementation of Higher Order Thinking Skills (HOTS) in the 2013 Curriculum Assessment}

Higher Order Thingking Skills (HOTS) is a type of instrument used to measure higher order thinking skills. Widana states that questions at the HOTS level in the context of assessment are used to measure a number of abilities, namely: 1) transferring one concept to another, 2) processing and applying information, 3) looking for references from a variety of different information, 4) using information to solve problems, and 5) critically examining ideas and information.

The application of HOTS to the assessment process in the 2013 curriculum refers to the preparation of instruments. In preparing HOTS-based instruments, it generally uses stimulus. The stimulus is the basis for making questions. In this context, the stimulus presented should be contextual and also interesting. The activity of making HOTS-based instruments is carried out by formulating material that will be the basis for questions (stimulus) in a particular context in accordance with the expected behavior.

In the making of HOTS-based questions, it is necessary to master theteaching material as well as the skill in writing questions (problem construction), and teacher's creativity in choosing stimulus questions in accordance with the situation and conditions of the area around the education unit. Broadly speaking, there are five main activities in developing HOTS-based instruments, including the following.

(1) Analyzing basic competencies which can be made HOTS-based questions

Basic competence is a set of abilities concerning attitudes, knowledge, and skills that must be possessed by students after learning a certain learning content. In the 2013 curriculum, these basic competencies are achieved coherently from the lowest knowledge to higher knowledge, ranging from knowing (C1), understanding (C2), implementing (C3), analyzing (C4), evaluating (C5), to creating (C6). In other words, not all basic competencies in the 2013 curriculum can be made HOTS-based questions.

The process of analyzing basic competency is used as a basis for arranging questions. The basic competency that can be made into a HOTS-basedquestions is the level of reasoning competency (level 3). This level includes the dimensions of the thought process of analyzing (C4), evaluating (C5), and creating (C6). At the level of analysis (C4) students are required to be able to specify parts, describe, organize, compare, and find implied meaning. At the level of evaluating (C5) students are required to form hypotheses, criticize, predict, assess, test, justify or blame. As for the creating level (C6) students are required to be able to design, build, plan, produce, find, update, perfect, strengthen, beautify, and tocompose.

The characteristics of basic competenciesincluded in the level of reasoning are basic competencies that require the ability to use reasoning and logic to make decisions (evaluation), predict and reflect, as well as the ability to formulate new strategies to solve nonroutine contextual problems. This is reinforced by using several operational verbs (KKO) which can be used as a reference feature. Some operational verbs (KKO) that are often used include: describe, organize, compare, construct hypotheses, criticize, predict, assess, test, conclude, design, build, plan, produce, find, update, perfect, strengthen, beautify, and compose.

(2)Arranging the test blueprint or table of specification

Test blueprint or table of specification test is a description of the competency and material to be tested. The purpose of preparing the test blueprint is to determine the scope and also as a guide in writing questions. A good test blueprint is expected to meet several requirements, namely: 1) it should be able to represent the contents of the syllabus/curriculum or material 
that has been taught precisely and proportionally; 2) its components are clearly described and easily understood; and 3) the material to be asked can be made to be questions.

In addition, the writing of the test blueprint also aims to help teachers write HOTS items. In general, thetest blueprint can be used to guide teachers in: 1) selecting basic competencies for which HOTS-based questions can be made, 2) choosing basic material related to main competencies to be tested, 3) formulating question indicators, and 4) determining levels cognitive problem. To be able to formulate this, the test blueprint can be presented in a matrix format that consists of at least a number of components, including a description of subjects, main competencies, basic competencies, subject matter, question indicators, and question numbers.

(2) Choosing interesting and contextual stimulus

Stimulus is the basis for making questions. This stimulus can be presented in the form of pictures, graphics, discourse, maps, and so forth. In the HOTS context, the stimulus presented is expected to have a contextual and attractive nature. An interesting stimulus means that it has never been found and can encourage students to look, read, and examine. While contextual stimulus means stimulus that is in accordance with reality in daily life, interesting, and encourages students to read.

In Indonesian context, stimulus can be taken from global issues such as maritime affairs, gender mainstreaming, disaster resilience, climate change, the dangers of drugs, nonviolence, defending the country, and reproductive health. Stimulus can also be raised from the problems that exist in the environment around the education unit such as culture, customs, cases in aregion, problems of information technology, science, economy, health, education, infrastructure, or varioussources found in certain regions. Teacher's creativity can affect the quality and variety of stimuli used in writing HOTS questions.

(3) Writing question items according to the test blueprint

The rules for writing HOTS-basedquestions are quite different from the rules for writing questions in general. The difference lies in the material aspects, while in the construction and language aspects are relatively the same. Questions written in HOTS-based questions must be preceded by stimulus. In addition to strengthening the literacy process of students, this stimulus also aims to direct students to be able to strengthen their skills in analyzing, connecting, and constructing answers.

Procedurally, the questions raised are preceded by an analysis of basic competencies, then described into test blueprint, broken down into question cards, and formed intointact questions.

(4) Making scoring guidelines (rubrics) or answer key

Making scoring guidelines is used as a reference in checking students' answers of the question. Scoring guidelines must be detailed and complete to reduce subjectivity in the assessment process.

Higher Order Thingking Skills (HOTS) in the 2013 Curriculum assessment aiming at improving teacher pedagogical skills can be implemented in several stages of evaluation. In the initial stages of learning, teachers can apply HOTS to measure students' initial abilities. This is done by making pre-test questions to determine the basic abilities of each student. After the basic ability is known, the teacher will combine it with the level of material difficulty and supporting capacity (infrastructure) to determine the minimum passing criteria $(\mathrm{KKM})$ in the learning process.

At the process and final stages of learning, the teacher can apply HOTS to measure the results of student learning achievement. This is done by creating a question instrument to see the level of success of students understanding the material that has been delivered by the 
teacher, both in terms of knowledge and skills. In addition, this measurement process can also be used as a reference by the teacher to determine the follow-up that will be carried out on students.

As for the follow-up stage, the teacher can apply HOTS to the measurement of the followup process, both in the form of enrichment and remedial. The HOTS-basedquestions presented at this stage can refer to the results of the previous measurements. If students get a score above the KKM (complete), then students can continue by working on the enrichment questions. However, if students get a score below the KKM (not complete), then students can work on remidial questions.

The formulation of comprehensive evaluation which is applied by making HOTS-based instruments will certainly maximize student learning outcomes. Besides being able to improve critical thinking skills, this activity will also make students have high competitiveness and have adequate literacy insight [14].

\section{Conclusion}

One of the ways to improve the quality of education is to strengthen teacher competency. Various teacher competencies are called pedagogical competencies, one of which is the teacher's ability to evaluate learning outcomes. In carrying out the evaluation process, teachers should conduct a comprehensive evaluation process by applying Higher Order Thingking Skills (HOTS). This comprehensive evaluation process can guarantee the success of the learning process and improve pedagogical abilities in order to realize teacher professionalism.

\section{References}

[1]. Indonesia PR. Undang-Undang tentang Guru dan Dosen. 14/2005 2005.

[2] Indonesia PR. Standar Nasional Pendidikan Republik Indonesia. 32/2013 2013.

[3] Indonesia PR. Undang-Undang Pendidikan Nasional. 14/2015 2013.

[4] Indonesia PR. PP No.13/2015 tentang Standar Nasional Pendidikan. Setneg, 13/2015 2015 p. 15 .

[5] Arikunto S. Dasar-Dasar Evaluasi Pendidikan. Jakarta: Bumi Aksara; 2013.

[6] Widana IW. Modul Penyusunan Soal Higher Order Thingking Skill (HOTS). Kementrian Pendidikan dan Kebudayaan. Jakarta; 2017.

[7] Andini DM, Supardi E. Kompetensi Pedagogik Guru Terhadap Efektivitas Pembelajaran Dengan Variabel Kontrol Latar Belakang Pendidikan Guru. J Pendidik Manaj Perkantoran. 2018;3(1):148.

[8] Arifin Z. Evaluasi pembelajaran. Vol. 8. Bandung: Remaja Rosdakarya; 2009.

[9] Zuldafrial. Strategi dan Pendekatan Pengelolaan Kelas. Pontianak: Pustaka Abuya; 2009.

[10] Sukmadinata NS. Metode Penelitian Pendidikan. Bandung: Remaja Rosdakarya; 2013.

[11] Fernandez R. Teachers 'Competence and Learners' Performance in the Alternative Learning System Towards an Enriched Instructional Program. Int Journalof Inf Technol Bus Manag. 2013;22(1):34.

[12] Dr. E. Mulyasa MP. Menjadi Guru Profesional. PT. Remaja Rosdakarya. 2008.

[13] Wagiran. Evaluasi Pembelajaran. Semarang: LP2M UNNES; 2018.

[14] I. K. Sudarsana et al., "Integrating Technology and Media in Learning Process," in Journal of Physics: Conference Series, 2019. 